\title{
Regional migration of agriculture labour to other sectors in Bidar district of Karanataka: A factorial analysis using Garrett's Scale
}

\author{
STEPHAN RAJ, A.D. NAIK, V.K. PATIL AND V.H. KAVYA
}

Received : 20.10.2015; Revised : 20.02.2016; Accepted : 20.03.2016

\begin{abstract}
Round the world, migration is a way of life for many of the poor people and has been for centuries. Globalization has radically altered the scale of migration all over the world. People are now more aware of opportunities elsewhere and it has become easier for them to travel and get employment. In this context, this paper is concerned with circular migration between the agriculture and construction sectors in Karnataka. The seasonal migration of agricultural laborers is not a new phenomenon in Karnataka and India. Britishers had mobilized labour force for commercial crop production, mining and for other administrative purposes during their rule. As a result of the defective policies of agricultural development the regional disparity is increasing even after independence leading to the increase in the seasonal migration of agricultural laborers. Agricultural labourers, especially in smaller villages away from towns and cities, are generally unskilled workers carrying on agricultural operation in the centuries old traditional ways. Most agricultural workers belong to the depressed classes, which have been neglected for ages. This movement has some time helped them to get the benefits of growth and development. In the state of Karnataka there is a wide gap between South and North Karnataka as far as development is concerned and this regional disparity has become a political issue. Many social, economic, political and psychological reasons pull them to migrate for survival and improvement of livelihood. The work participation ratio of North Karnataka is even though less compare to South Karnataka but still the agriculture laborers migrating from agriculture to other sectors. This paper is an effort to identify some of the main causes for the agricultural labour migration from north Karnataka to south Karnataka and capital city of Telangana and Maharastra.
\end{abstract}

KEY WORDS : Agriculture labour, Bidar, Karnataka labour force, Regional migration

How to cite this paper: Raj, Stephan, Naik, A.D., Patil. V. K. and Kavya, V. H. (2016). Regional migration of agriculture labour to other sectors in Bidar district of Karanataka: A factorial analysis using Garrett's Scale. Internat. J. Com. \& Bus. Manage, 9(1) : 53-57.

\section{MEMBERS OF THE RESEARCH FORUM}

Correspondence to:

STEPHAN RAJ, Department of Agribusiness Management, University

of Agricultural Science, DHARWAD (KARNATAKA) INDIA

Email: stephanbidar@gmail.com

\section{Authors' affiliations:}

A.D NAIK, V.K. PATIL AND V.H. KAVYA, Department of Agribusiness Management, University of Agricultural Science, DHARWAD (KARNATAKA) INDIA 